\title{
UV SPECTROPHOTOMETRIC ANALYSIS AND VALIDATION OF OSELTAMIVIRPHOSPHATE IN PURE AND PHARMACEUTICAL FORMULATION
}

\author{
SACHIN A. YANJANE ${ }^{*}$, SHRISHAIL M. GHURGHURE, VINOD K. MATOLE \\ D. S. T. S. Mandal's College of Pharmacy, Solapur 413004 Maharashtra, India \\ Email: sachinyanjane11@gmail.com
}

Received: 25 Nov 2019, Revised and Accepted: 22 Jan 2020

\section{ABSTRACT}

Objective: A new, simple, economical, precise, sensitive, linear, accurate, rapid UV spectrophotometric method has been developed for the estimation of Oseltamivir Phosphate in pure form and pharmaceutical formulation.

Methods: This UV method was developed using Methanol as a solvent. In the present method, the wavelength selected for analysis was $218 \mathrm{~nm}$. UVVisible double beam spectrophotometer (Systronic 2201) was used to carry out spectral analysis. The ICH guidelines were used to validate the method.

Results: The method was validated for linearity, range, accuracy, precision, robustness, LOD and LOQ. Linearity was found in the range of 10$50 \mu \mathrm{g} / \mathrm{ml}$. Accuracy was performed by using a recovery study. The amount of drug recovered was found to be in the range of $99.01-100.1 \%$. The $\%$ RSD value was found to be less than 2 .

Conclusion: The developed UV spectrophotometric method was found to be simple, economic, sensitive, easy, accurate, linear, specific and highly sensitive and can be used for routine estimation of Oseltamivir Phosphate.

Keywords: Oseltamivir Phosphate, Methanol, UV-Visible spectrophotometric method, Method validation

(C) 2020 The Authors. Published by Innovare Academic Sciences Pvt Ltd. This is an open access article under the CC BY license (http://creativecommons.org/licenses/by/4.0/) DOI: http://dx.doi.org/10.22159/ijcpr.2020v12i2.37505. Journal homepage: https://innovareacademics.in/journals/index.php/ijcpr

\section{INTRODUCTION}

UV-Visible spectrophotometry is one of the most frequently employed techniques in pharmaceutical analysis. By using UVVisible spectrophotometry, the amount of ultraviolet or visible radiation absorbed by an analyte in a solution is determined [1].<smiles>CCOC(=O)C1=C[C@H](OC(CC)CC)[C@H](NC(C)=O)[C@H](N)C1</smiles>

Fig. 1: Chemical structure of oseltamivir phosphate [2]

Oseltamivir Phosphateis also is known as Tamiflu. Its molecular formula is C16H28N204. IUPAC name of Oseltamivir Phosphate is ethyl (3R, 4R, 5S)-5-amino-4-acetamido-3-(pentan-3-yloxy) cyclohex-1-ene-1-carboxylate (fig. 1). Oseltamivir is administered orally, it is an antiviral drug for the management of influenza A and $\mathrm{B}$ infections in children $>1 \mathrm{y}$ and adults of all ages [3]. Oseltamivir phosphate is an ethyl ester prodrug requiring ester hydrolysis for conversion to the active form, oseltamivir carboxylate. Oseltamivir carboxylate is an inhibitor of influenza virus neuraminidase affecting the release of viral particles [4]. The concentrations of oseltamivir carboxylate required for inhibition of influenza virus in cell culture were highly variable depending on the assay method used and the virus tested. Standard dose of oseltamivir in adults is $75 \mathrm{mg}$, while children have unit doses that are selected on the basis of body weight. Oral capsule (35, 40 and $75 \mathrm{mg}$ ) and suspension formulations are now readily available [5]. Antiviral drugs are a class of medication used specifically for treating viral infections rather than bacterial ones. Most of the antiviral drugs are available for treating various types of viral diseases such as, HIV, influenza A and $B$, herpes viruses, hepatitis B and C viruses [6].

\section{MATERIALS AND METHODS}

\section{Instruments}

UV/Visible double beam spectrophotometer Systronic 2201. Standard cuvettes having $10 \mathrm{~mm}$ of path length are used for analysis. Ultra Sonicator (micro clean-103) was used to sonicate the formulation sample. Drug sample was weighed by using an electronic analytical balance (Shimadzu AY220).

\section{Chemicals and reagents}

Active pharmaceutical ingredient of Oseltamivir Phosphate is gifted as a sample from Zydus Cadila Healthcare Ltd, the pharmaceutical company, Vadodara, Gujarat. Marketed formulation of Oseltamivir Phosphate was procured from a local pharmacy.

\section{Experimental work}

Method development

Preparation of standard stock solution of oseltamivir phosphate

Accurately weighed $10 \mathrm{mg}$ of drug was transferred to $10 \mathrm{ml}$ volumetric flask and dissolved in methanol, this was considered as a stock solution. From stock solution $0.1 \mathrm{ml}, 0.2 \mathrm{ml}, 0.3 \mathrm{ml}, 0.4 \mathrm{ml}, 0.5$ $\mathrm{ml}$, were taken and was make up the volume to $10 \mathrm{ml}$ with methanol to get respective concentrations of $(10,20,30,40$ and 50$) \mu \mathrm{g} / \mathrm{ml}$. Prepared samples were analyzed by using an ultraviolet double beam spectrophotometer at $\lambda \max 218 \mathrm{~nm}$.

\section{Assay of oseltamivir phosphate capsules}

Weigh 20 Capsule of Oseltamivir Phosphate equivalent to10 mg of Oseltamivir Phosphate was weighed, transferred into $10 \mathrm{ml}$ volumetric flask and dissolved in methanol. This solution was sonicated for $10 \mathrm{~min}$ and the final volume was made up to the mark with water. $1 \mathrm{ml}$ of solution was transferred into $10 \mathrm{ml}$ volumetric 
flask and diluted up to $10 \mathrm{ml}$ with methanol. The absorbance of this solution was measured at $218 \mathrm{~nm}$.

\section{RESULTS AND DISCUSSION}

\section{Method validation}

The method was validated for several parameters like Linearity, Accuracy, Precision, Robustness, Limit of Detection (LOD), Limit of
Quantification (LOQ) and Specificity of Oseltamivir Phosphate capsule [7-10].

\section{Linearity and range}

The linear relation between absorbance and concentration of drug was evaluated using three replicates over concentration rangein10$50 \mu \mathrm{g} / \mathrm{ml}$ by making the replicates (table 1 and fig. 2).

Table 1: Results of linearity

\begin{tabular}{lll}
\hline S. No. & Concentration $(\mu \mathrm{g} / \mathbf{m l})$ & Absorbance \\
\hline 1 & 10 & 0.04 \\
2 & 20 & 0.093 \\
3 & 30 & 0.142 \\
4 & 40 & 0.192 \\
5
\end{tabular}

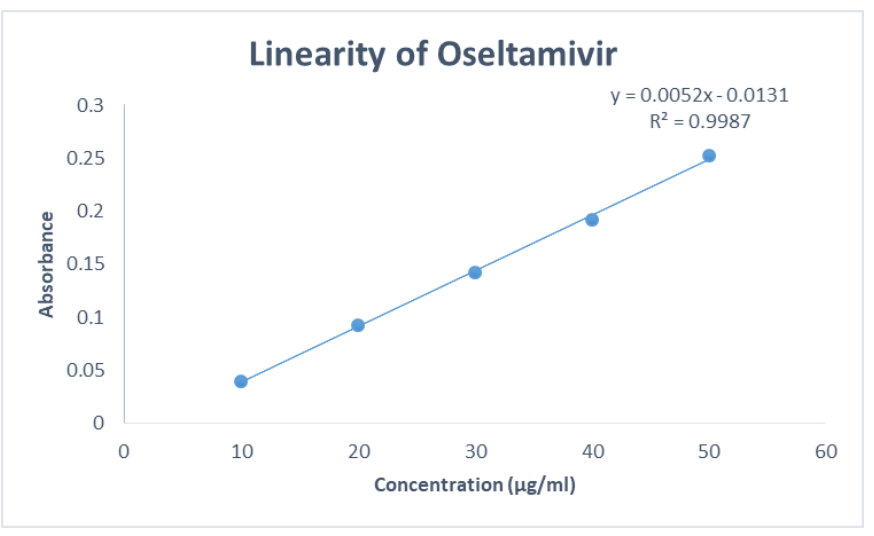

Fig. 2: Calibration curve for oseltamivir phosphate

The wavelength for linearity was scanned at $218 \mathrm{~nm}$. By taking five different concentrations for linearity the regression coefficient was found to be 0.9987 i.e. in the limit of standard. Hence the linearity parameter was found to be validated.

\section{Accuracy}

The percentage recovery results for Oseltamivir Phosphate were varied from $99.01 \%$ to $100.1 \%$ at three different concentration levels that is $(30,40,50 \mu \mathrm{g} / \mathrm{ml})$, and the results were shown in table 2. Based on the \% recovery data, it was concluded that the developed method is capable for the estimation of Oseltamivir Phosphate drug substance and is adequate for routine analysis.

\section{Precision}

Method precision was determined by analyzing the test solution of six determinations, and the observed values of \% RSD were shown in table 3 and 4 . The \% RSD for Oseltamivir Phosphate in the test solution for six formulations was not more than $2 \%$. The solution was analyzed in 6 replicates for intra-day precision and in two successive days for inter-day precision.

Results confirmed that the precision of the method was found to be accepted. Precision results were given in table 3 and table 4 for intra and inter-day precision respectively.

\section{Robustness}

The robustness of the proposed method was performed by preparing the standard solutions and test solutions of Oseltamivir Phosphateat $100 \%$ level were analyzed by a change in wavelength for absorbance readings. The wavelength selected was $\pm 2 \mathrm{~nm}$ to the $\lambda \max$, i.e., 218 and $234 \mathrm{~nm}$ for Oseltamivir Phosphate drug for standard and sample solutions. Robustness was carried out on two different instruments and also carried out by using two different analysts (table 5).

Table 2: Results of accuracy

\begin{tabular}{lllll}
\hline Name of drug & Recovery levels & Concentration $(\boldsymbol{\mu g} / \mathbf{m l})$ & Amount recovered & \% Recovery with SD \\
\hline \multirow{3}{*}{ Oseltamivir } & $80 \%$ & 30 & 30.002 & $100.02 \pm 0.80$ \\
& $100 \%$ & 40 & 40.001 & $100.01 \pm 0.26$ \\
& $120 \%$ & 50 & 50.004 & $100.02 \pm 0.5$ \\
\hline
\end{tabular}

Table 3: Results for Intra-day precision

\begin{tabular}{|c|c|c|}
\hline S. No. & Concentration $(\mu \mathrm{g} / \mathrm{ml})$ & Absorbance \\
\hline 1 & 30 & 0.142 \\
\hline 2 & 30 & 0.143 \\
\hline 3 & 30 & 0.141 \\
\hline 4 & 30 & 0.142 \\
\hline 5 & 30 & 0.143 \\
\hline 6 & 30 & 0.144 \\
\hline SD & & 0.001049 \\
\hline$\%$ RSD & & $0.736006 \%$ \\
\hline
\end{tabular}


Table 4: Results for Inter-day precision

\begin{tabular}{llcc}
\hline S. No. & Concentration $(\boldsymbol{\mu g} / \mathbf{m l})$ & Absorbance (Day1) & Absorbance (Day2) \\
\hline 1 & 30 & 0.142 & 0.144 \\
2 & 30 & 0.143 & 0.143 \\
3 & 30 & 0.141 & 0.145 \\
4 & 30 & 0.142 & 0.142 \\
5 & 30 & 0.143 & 0.143 \\
6 & 30 & 0.144 & 0.144 \\
SD & & 0.001049 & 0.001049 \\
\%RSD & & $0.736006 \%$ & $0.730877 \%$ \\
\hline
\end{tabular}

For Intra-day and the inter-day precision relative standard deviation is in the limit.

Table 5: Results for robustness

\begin{tabular}{lll}
\hline Wavelength & $218 \mathrm{~nm}$ & $234 \mathrm{~nm}$ \\
Concentration & $25 \mu \mathrm{g} / \mathrm{ml} / \mathrm{ml}$ & 0.113 \\
& 0.111 & 0.112 \\
Absorbance & 0.112 & 0.111 \\
& 0.114 & 0.112 \\
& 0.112 & 0.111 \\
SD & 0.111 & 0.114 \\
\% RSD & 0.115 & 0.001169 \\
\hline
\end{tabular}

By change in concentration and wavelengths i.e. $218 \mathrm{~nm}$ and $234 \mathrm{~nm} \% \mathrm{RSD}$ is less than $2 \%$ i.e. within the range. So the parameter was validated.

Table 6: Results for ruggedness

\begin{tabular}{lll}
\hline Concentration & Analyst 1 & Analyst 2 \\
\hline & 0.093 & 0.092 \\
& 0.092 & 0.091 \\
& 0.094 & 0.095 \\
& 0.091 & 0.093 \\
$\mathrm{SD}$ & 0.095 & 0.094 \\
$\% \mathrm{RSD}$ & 0.093 & 0.092 \\
& 0.001414 & 0.001472 \\
& $1.52066 \%$ & $1.585594 \%$ \\
\hline
\end{tabular}

By change in analyst and laboratory, there is no effect on absorbance with the same conditions (table 6). Hence, the parameter was validated.

\section{Ruggedness}

The degree of reproducibility of test results of the same sample within different laboratories and different analysts under the same condition with the same concentration.

\section{Limit of detection (LOD)}

The limit of detection (LOD) is the lowest concentration of an analyte in a sample that can be detected but not necessarily to be determined quantitatively under specified experimental conditions. The limit of detection, as calculated statistically for Oseltamivir Phosphate was found to be $2.08 \mu \mathrm{g} / \mathrm{ml}$. The low value of Limit of detection suggests that a very low concentration of drugs can be detected.

\section{Limit of quantitation (LOQ)}

The limit of quantification (LOQ) is the lowest concentration of an analyte in a sample that can be quantitatively determined within an acceptable level of accuracy and precision under the stated operational conditions of the method. The limit of quantification was found to be $6.93 \mu \mathrm{g} / \mathrm{ml}$. Hence, a very low concentration of drug can be quantified satisfactorily.

\section{CONCLUSION}

The developed UV spectrophotometric method was found to be simple, economic, easy, accurate, precise, linear, specific, and highly sensitive and can be used for routine estimation of Oseltamivir Phosphate.

\section{ACKNOWLEDGMENT}

The authors are thankful to the Principal Dr. R. Y. Patil sir, DSTS Mandal's College of Pharmacy Solapur, for providing the facilities and continuously support for carried out this Research Programme.
The authors are also thankful to Prof. Shrishail M. Ghurghure for providing consistent support and timely guidance.

\section{FUNDING}

Nil

\section{AUTHORS CONTRIBUTIONS}

All the authors have contributed equally.

\section{CONFLICT OF INTERESTS}

Declare none

\section{REFERENCES}

1. Raut CS, Charge DS, Dhabale PN, Gonjari ID, Hosmani AH, Hosmani AH. Development and validation of oseltamivir phosphate in fluvir ${ }^{\circledR}$ by uv-spectrophotometer. Int J Pharma Tech Res 2010;2:363-6.

2. Sahu SA, Acharya SA, Chourasia AK, Asati AP. Method development and validation of oseltamivir phosphate in bulk drug by uv spectroscopy. Int J Pharm Pharm Sci 2012;4:194-6.

3. Davies BE. Pharmacokinetics of oseltamivir: an oral antiviral for the treatment and prophylaxis of influenza in diverse populations. J Antimicrob Chemother 2010;65:5-10.

4. Pandian PM, Kannan KK, Manikandan MP, Manavalan Rk Formulation and evaluation of oseltamivir phosphate capsules. Int J Pharm Pharm Sci 2012;4:342-7.

5. https://www.rochecanada.com/PMs/Tamiflu/Tamiflu_PM_E.p df. [Last accessed on 02 Oct 2019]

6. Ward PP, Small IJ, Smith JI, Suter PP, Dutkowskr RO. Oseltamivir (Tamiflu) and it's potential for use in the event of an influenza pandemic. J Antimicrob Chemother 2005;5:5-21. 
7. Arsova Sarafinovska ZK, Ameti AP, Slavkovska JJ, Starkoska KT. A simple isocratic RP-HPLC method for quality control of oseltamivir capsule. Maced J Chem Chem Eng 2012;32:205-15.

8. Bano TS, Dudhe RR, Kumar NK. Development and validation of RP-HPLC method for the determination of oseltamivir phosphate API. J Progressive Res Chem 2015;2:69-72.
9. Rashed NS, Abdallah OM, Said NS. Validated stability-indicating method for determination of oseltamivir phosphate. Br J Pharm Res 2017;16:1-9.

10. ICH, Q2 (R1) Validation of analytical procedures: text and methodology, International conference on harmonization; 1996. 